\title{
An Empirical Analysis of Stochastic Implications of Stock Price Movements in the Nigerian Capital Market
}

\author{
Ayakeme E. Whisky \\ De-Corporate Associates Limited \\ Yenagoa, Bayelsa State, Nigeria \\ E-mail: ayakswhisky@yahoo.com
}

Received: Nov. 01, 2015

Accepted: Dec. 14, 2015

Published: Dec. 18, 2015

doi: 10.5296/ifb.v2i2.8743

URL: http://dx.doi.org/10.5296/ifb. v2i2.8743

\begin{abstract}
The study provides further empirical insight to the behavior of stocks in four selected sectors of the Nigerian economy using the Runs and GARCH techniques to analyze monthly stock data for the period January 2006 to December, 2011. The results of the Runs Test do not support random movements of stocks in all the sectors, indicating homoscedasticity. The GARCH estimated model also shows volatility clustering in all the sectors except the Agricultural sector, which implies weak form inefficiency of the Nigerian capital market.
\end{abstract}

Keywords: Randomness, stochastic movements, runs, GARCH, homoscedasticity, heteroscedasticity, Nigeria 


\section{Introduction}

Stock prices are generally presumed to move at random, a characteristic that makes stocks not only unpredictable but the market efficient, whether it is traded in developed or emerging capital market. It is, in other words, a normal expectation for prices of stocks to change almost every minute to defy predictability. Despite this expected trend some studies have indicated that stock prices are homogenous, showing evidence of consistency over a definite time horizon. Thus, the hypothesis of stochastic or random stock movements has generated curious interest in determining the efficiency of capital markets, including Nigeria.

When stocks display stochastic tendency in a market, such market is weak-form efficient. It means investors cannot outperform the market through speculative activities (Pele \& Voineagu, 2008; Adelegan, 2009; Okpara, 2010). This is in contrast with the findings of Khan \& Ikam, 2010; Nwosa \& Oseni, 2011 that said stock prices are homogenous and not stochastic.

The Nigerian Capital Market, though being in existence since 1960, has been undergoing gradual reforms. Still not considered deep enough as an emerging market, its market capitalization is reportedly lower than the country's GDP, when compared to South Africa where the market capitalization of the Johannesburg Stock Exchange is reportedly 239\% of the GDP. As part of measures to build investors' confidence, the reforms introduced the central securities clearing system (CSCS), which is an automated clearing, settlement and delivery system. This was in addition to directly linking the operations of the NSE to Reuters International System to meet the objective of quick dissemination of information. Unimpeded and quick access to information is an essential characteristic of an efficient market.

The cumulative effect of these reforms was an enhanced market capitalization that grew to N11.478 trillion at the beginning of the year 2015. Unfortunately, the market has been in a prolonged bearish trend, shedding investors' worth by N1.98 trillion since the beginning of the year to the present capitalization at N9.495 trillion as at November 2015. The bearish trend the market is currently experiencing is a direct fall out of the depressing economic fortunes of the country given the dipping effect of global oil prices, as a monolithic economy. Consequently, the direction of fiscal policies has created substantial concerns for investors, particularly offshore investors, who had hitherto seen promising prospects in the Nigerian Capital Market, to divest their investments. It therefore calls for careful planning on the part of investors to reap good returns from their investments.

Part of the planning requirements demands knowing the stock an investor desires to invest on; the value of the stock in question and its financial position; its characteristics and potentials and how well these meet the investor's investment objectives. Therefore, the approach of this study to evaluate the Nigerian Stock Exchange on sectoral basis is to assist investors identify clear choice of opportunities to invest based on known performances of each sector to meet their investment objectives. Understanding the stochastic behavior of the selected stocks of the sectors under study to determine their empirically validity in sync with the efficient market hypothesis is essential for investors' decision to invest. 
The rest of the paper is presented as follows: literature review, methodology and data, results, conclusion and recommendations.

\section{Literature Review}

The study of Grossman \& Stiglitz (1980) on the impossibility of informationally efficient markets, by calculating the expected utility of the informed and the expected utility of the uninformed investor, by applying Constant Absolute Risk-Aversion Model (CARM) to estimate budget constraints of an investor, to determine individual's utility maximization, equilibrium price distribution, existence of equilibrium and characterization theorem, show capital markets to be informationally efficient. The study assumed that both investors are identical ex-ante, the only difference is whether the informed and uninformed have spent money to obtain information. The study extended the noisy rational expectations model introduced by Robert Lucas, which Jerry Green applied to the study of information flows. Jenning \& Stark (1985) conducted an investigation into the speed of stock price adjustment to new information using PW stochastic process tests, on how stratified sample data of last forecast after the announcement of earnings estimates of the Standard and Poor's Corporation and 40 other professional security analysts, affect stock prices. The study revealed that announcements with anticipated high information content were associated with price adjustment processes, while those with low information content showed less evidence of anticipatory price movement, indicating price influences with high content announcement.

However, studies in some emerging markets like the Romanian capital market, the Indian capital market, Dhaka Stock Market of Bangladesh show mixed results. Pele \& Voineagu (2008), in their investigation to determine the efficiency of the Romanian capital market, adopted a model for decomposing time series of prices natural logarithms into the sum of a random walk and a stationary component for long-horizons returns. The study evaluated the top 10 stocks that account for $60 \%$ of market capitalization using parameters of the autoregressive process where the market is presumed efficient if $\mathrm{p}=1$ and inefficient if $\mathrm{p}=/ 1$, and concluded that the market was efficient in the weak form. Whereas Khan \& Ikram (2010) investigated the impact of foreign institutional investors with respect to the influence of publicly available information on asset returns and concluded that the Indian capital market is semi-strong form efficient. The study revealed that the activities of the Foreign institutional investment (FII) verily create instant reaction in the market, thus no investor can outperform the market. Using data consisting of monthly averages of two major stocks from 1st April 2000 to 31st March, 2010, the study adopted correlation and regression techniques and found that there is a significant impact on Indian capital market by the activities of foreign institutional investors. Mobarek \& Keasey (2000) in determining whether the Dhaka Stock Market of Bangladesh is weak-form efficient as an emerging market, adopted parametric tests of auto-regression and auto-regressive-integrated-moving-average (ARIMA) to estimate daily market returns covering a period of 1st January, 1988 to 31st December, 1997 and also non-parametric tests of Koglomorov-Smirnov goodness of fit test and runs test and concluded that it is not weak-form efficient.

We thus find that the results from the study of the two forms of markets, developed and 
emerging markets, do not present uniform results. This presents a veritable need for the continuous investigation of the Nigeria Stock Exchange, which earlier studies also showed mix conclusions as well.

For instance, Ayadi (1984), Okpara (2010), Samuel \& Yacout (1981) as reported in Adelegan (2009) and Olowe (1999) as reported by Okpara (2008) examined whether stock prices in Nigeria follow a predictable path and discovered that share price movements in Nigeria follow a random walk. We note that these earlier studies adopted the less rigorous non-parametric tests. Both Ojo \& Azeez (2012) and Ajao \& Osayuwu (2012), using parametric tests of autoregressive heteroscedasticity (ARCH) introduced by Engel (1982) and the Generalized Autoregressive Conditional Heteroscedasticity (GARCH) introduced by Bollerslev (1986) examined the form of efficiency of the Nigerian capital market. The studies corroborated the earlier findings that the Nigerian capital market is efficient in the weak form. The studies used data of the All Share Index (ASI) from the Nigerian stock exchange covering the period 1986 to 2010 (Ojo \& Azeez, 2012) and 2001 to 2010 (Ajao \& Osayuwa, 2012). The findings of Ojo \& Azeez (2012) which specifically tested whether the Nigerian capital market is semi-strong efficient supported the findings of Adelegan (2009) whose earlier study also found that the Nigerian capital market is not semi-strong efficient. The study used share price cutting across the pre and post liberalization regimes, concentrating on the 3-day, 21-day and 61-day event windows in the short-run for the period 1990 to 1999 in evaluating the speed of adjustment to announcements of dividend payments and omissions for 742 announcement dates.

But Emenike (2008) investigated the Nigerian capital market to determine whether it is efficient across time, to know if efficiency could change over time. Using the monthly All Share Index (ASI) of the NSE, the study considered three distinct periods beginning from January 1985 to December 1992; January 1993 to December 1999 and January 2000 to December 2007. Using non-parametric normality test and runs test, the study showed that the Nigerian capital market is not efficient in the weak form across time. Also Nwosa \& Oseni (2011) examined the efficiency of the Nigerian stock market for the period 1986 to 2010, using the econometric tools of serial autocorrelation and regression analysis, and revealed that the Nigerian capital market is informationally inefficient. The studies show that stock prices do not exhibit random walk. According to their work, the lag value of stock price is significant, implying that previous stock prices can successfully predict current stock prices.

Given the above scenario of conflicting previous research findings with respect to the form of efficiency of the Nigerian capital market, our recourse to determine the sectoral efficiency of the market is whether each of the sectors will correlate the overall market position. And the results will provide guide for investors' decisions.

\section{Methodology}

In this study, we used the non-parametric technique of Runs test in determining whether stock prices in the Nigerian capital market move at random based on its frequently varied use in previous researches, particularly in emerging markets (Vulic \& Emenike, 2008; Barnes, 1986; Claessens et al., 1995; Dickinson \& Muragu, 1994; Simon \& Larvea, 2004; Rahman \& 


\section{Macrothink}

Hossain, 2006 as reported in Emenike, 2008). A run is defined as a succession of one or more identical symbols, which are followed and preceded by a different symbol or no symbol at all (Wang, 2003). As Gujarati \& Sangeetha (2007) posited, while too many runs indicate negative correlation too few runs may suggest positive autocorrelation. In undertaking the runs test Gujarati (2007) expressed the Mean, Variance and expected approximated probability as shown below:

$$
\begin{gathered}
\text { Mean: } E(R)=\frac{2 N 1 N}{{ }_{2}}+1 \\
\text { Variance: } \sigma_{R}^{2}=\frac{2 N 1 N_{2}\left({ }^{2 N 1 N}{ }_{2-}\right)}{(N) 2(N-1)} \\
\operatorname{prob}\left[E(R)-196 \sigma_{R} \leq R \leq E(R)+1.96 \sigma_{R}\right]=0.95
\end{gathered}
$$

The $\mathrm{Z}$ statistics gives the probability of the difference between the actual and expected runs.

$$
Z=\frac{R-M}{\sigma_{R}^{2}}
$$

Where:

$\mathrm{N}$ : total number of observation $=\mathrm{N} 1+\mathrm{N} 2$

$\mathrm{N} 1=$ number of + symbols (i.e + residuals)

$\mathrm{N} 2=$ number of - symbols (i.e - residuals)

$\mathrm{R}=$ number of runs

A further application of the parametric test, GARCH, which allows for time variant conditional variance and nonlinearities in generating mechanism (Okpara, 2010) is used to corroborate the findings of the Runs test. Adapting Brook's (2008) presentation, the GARCH model, which can be used to interpret the current fitted variance and information about volatility during the previous period, is expressed as:

$$
\sigma_{t}^{2}=\alpha_{0}+\alpha_{1} \varepsilon_{t-1}^{2}+\beta \sigma_{t-1}^{2}
$$

Where:

$\sigma^{2}=$ Conditional Variance

$\alpha_{0}=$ Constant

$\alpha_{1} \varepsilon_{\mathrm{t}-1}^{2}=$ Information about volatility during the previous period

$\beta \sigma_{\mathrm{t}-1}^{2}=$ Fitted variance during the previous period

\subsection{Data}

Data for this study, the daily stock prices, sourced from the website of Central Securities and 
Clearing system (http:/www.cscsnigerialtd.com), was downloaded in Microsoft excel format and converted into monthly balances. We further sourced the monthly balances of the Nigerian Stock Exchange All Shares index (ASI) from the fat book of the Nigerian Stock Exchange.

\section{Data Analysis}

Table 1 reports the test of the random movement of returns in the agricultural sector using the Runs test. The results show that observed z-statistics value of 1.187 is less that the critical value of 1.645. Therefore, we cannot reject the null hypothesis that the series of returns do not move randomly, thus indicating the prevalence of memory. Table 2 shows that there is no significant relationship between return and volatility given that the z-critical of 1.645 is greater than the observed z-statistics at value -1.012195 . The observed negative $\mathrm{z}$-statistics value is further indicative of an inverse relationship between volatility and returns. There is also no volatility clustering and no presence of ARCH or GARCH since the combined value of the coefficients is only 0.258.The Granger test shows a unidirectional relationship.

The runs test shows investors can conveniently use previous returns to predict future returns. This certainly confers advantage on market participants and analysts who indulge in the use of past data to predict future outcomes to outperform the market since the series of returns do not have stochastic movement. The study further shows that the risk-return relationship is not only insignificant but also inverse in the agricultural sector. Investment in agriculture though preferred but usually not attractive because of perceived high volatility. Therefore performance of the agricultural sector may not have been strictly defined by market forces but due to government intervention. Given the employment potentials of the sector, government's intermittent interventions in forms of grants and subsidies constitute the occasional stimulus to drive the sector. The volatility and returns relationship in the mean variance equation of the GARCH Model further elucidates that the agricultural sector of the Nigerian capital market is not efficient in the weak form.

Table 1. Application of runs test for the random movement of agricultural sector stocks

\begin{tabular}{|c|c|}
\hline & RS \\
\hline Test Valuea & 0.2 \\
\hline Cases $<$ Test Value & 36 \\
\hline Cases $>=$ Test Value & 36 \\
\hline Total Cases & 72 \\
\hline Number of Runs & 42 \\
\hline Z & 1.187 \\
\hline Asymp. Sig. (2-tailed) & .235 \\
\hline
\end{tabular}




\section{Macrothink}

Table 2. Application of GARCH in testing for agricultural sector stocks random movements

\begin{tabular}{|c|c|c|c|c|}
\hline Variable & Coefficient & std. Error & z-Statistic & Prob. \\
\hline VOLRS & -7.339240 & 7.250817 & -1.012195 & 0.3114 \\
\hline RESID(-1)^2 & 0.104487 & 0.172648 & 0.605205 & 0.5450 \\
\hline GARCH(-1) & 0.158392 & 0.816374 & 0.194018 & 0.8462 \\
\hline
\end{tabular}

At an observed z- value of -1.816 , which is less than the critical value of 1.645 at $5 \%$ degree of freedom, table 3 shows that the series of returns do not move randomly. This means there is presence of runs or the market has memory. Therefore the impact of previous returns on current returns cannot be ruled out. From the mean equation in table 4, there is a positive relationship between return and volatility given the Z-statistics of 42.29. Given that the combined coefficients in the ARCH and GARCH in the variance equation are approximation 1, there was volatility clustering of the returns. The presence of ARCH and GARCH further showed that there was no randomness in the movement of the returns. The calculated F-statistics values in table 5 are both less than the critical value of 2.37. We do not therefore reject the null hypothesis that neither volatility nor returns Granger cause the other in the automobile sector. This finding is however not in tandem with theory.

Tables 3. Application of runs test for the random movement of automobile sector stocks

\begin{tabular}{|c|c|}
\hline & RS \\
\hline Test Value $^{\mathrm{a}}$ & .00 \\
\hline Cases $<$ Test Value & 32 \\
\hline Cases $>=$ Test Value & 40 \\
\hline Total Cases & 72 \\
\hline Number of Runs & 29 \\
\hline $\mathrm{Z}$ & 1.816 \\
\hline Asymp. Sig. (2-tailed) & .069 \\
\hline
\end{tabular}

Table 4. Application of GARCH in testing for automob

\begin{tabular}{|c|c|c|c|c|}
\hline Variable & Coefficient & std. Error & z-Statistic & Prob. \\
\hline VOLRS & 4.321934 & 0.102205 & 42.28694 & 0.0000 \\
\hline RESID(-1) 2 & -0.043669 & 0.003937 & -11.09199 & 0.0000 \\
\hline GARCH(-1) & 1.026246 & 0.006165 & 166.4500 & 0.0000 \\
\hline
\end{tabular}


Table 5. The cause and effect of volatility and returns in the automobile sector

\begin{tabular}{|c|c|c|c|}
\hline Null Hypothesis: & Obs & F- Statistics & Probs \\
\hline VOLRS does not Granger Cause RS & 70 & 0.95175 & 0.3914 \\
\hline RS does not Granger Cause VOLRS & & 0.82379 & 0.4433 \\
\hline
\end{tabular}

From the results in table 6 , we observed z- statistics value of -2.374 is less than the critical value of 1.6449.We cannot therefore reject the null hypothesis that the series of returns do not move randomly. In fact, the results showed there was presence of runs and the market has memory. The mean equation in table 7 reveals that there is positive and significant relationship between volatility and returns. In the variance equation, we observed volatility clustering and the presence of ARCH and GARCH since the sum of the coefficients approximates 1.32. The calculated F-statistics in the test of volatility compared to the critical value of 2.37 suggests that we cannot reject the null hypothesis. This, however, is not applicable to the test of returns, which calculated F-statistics is greater than the critical, thus indicating that we can reject the null hypothesis. The unidirectional relationship between volatility and returns in the banking sector indicates that investors can use returns to predict volatility. In other words, where the returns of an asset of this sector is noticed to be high, such asset is presumably high in risk and when the return is low, it presupposes low risk.

Table 6. Application of runs test for the random movement of banking sector stocks

\begin{tabular}{|c|c|}
\hline & RS \\
\hline Test Value $^{\mathrm{a}}$ & -.02 \\
\hline Cases Test Value & 36 \\
\hline Cases $>=$ Test Value & 36 \\
\hline Total Cases & 72 \\
\hline Number of Runs & 27 \\
\hline $\mathrm{Z}$ & -2.374 \\
\hline Asymp. Sig. (2-tailed) & .018 \\
\hline
\end{tabular}

Table 7. Application of GARCH in testing for banking sector stocks random movements

\begin{tabular}{|c|c|c|c|c|}
\hline Variable & Coefficient & std. Error & z-Statistic & Prob. \\
\hline VOLRS & 0.303111 & 1.136815 & 0.266632 & 0.800 \\
\hline RESID(-1) 2 & 0.787034 & 0.390358 & 2.016186 & 0.044 \\
\hline GARCH(-1) & 0.542846 & 0.127496 & 4.257755 & 0.000 \\
\hline
\end{tabular}

The results from the runs test in table 8 shows that the calculated z-statistic value of -1.899 is less than the critical value of 1.645, we cannot therefore reject the null hypothesis that the series of returns do not move randomly. It means investors in this sector can conveniently 
predict future returns with previous returns. This indicates weak form inefficiency. The mean equation in table 9 indicates that there is positive relationship between volatility and returns, which is significant. The volatility coefficient of 0.640 shows that volatility could influence returns up to $64 \%$. The variance equation also shows that there is the presence ARCH and GARCH, given that the sum of coefficients is greater than 1, implying volatility clustering or pooling of the returns. While we do not reject the null hypothesis that volatility does not Granger cause returns in the beverages sector since the observed F-statistics value is less that the critical, we do reject the null hypothesis that returns does not Granger cause volatility. There is therefore a unidirectional relationship between volatility and returns in the beverages sector. This finding corroborates the results of the banking sector where we discovered that returns can be used to predict the riskiness of assets.

Table 8. Application of runs test for the random movement of beverages sector stocks

\begin{tabular}{|c|c|}
\hline & RS \\
\hline Test Value $^{\mathrm{a}}$ & .00 \\
\hline Cases $<$ Test Value & 36 \\
\hline Cases $>=$ Test Value & 36 \\
\hline Total Cases & 72 \\
\hline Number of Runs & 29 \\
\hline $\mathrm{Z}$ & -1.899 \\
\hline Asymp. Sig. (2-tailed) & .058 \\
\hline
\end{tabular}

Table 9. Application of GARCH in testing for beverages sector random movements

\begin{tabular}{|c|c|c|c|c|}
\hline Variable & Coefficient & std. Error & z-Statistic & Prob. \\
\hline VOLRS & 0.640794 & 1.815452 & 0.352967 & 0.7241 \\
\hline RESID(-1) 2 & 0.515304 & 0.258933 & 1.990110 & 0.0466 \\
\hline GARCH(-1) & 0.565833 & 0.123910 & 4.566487 & 0.0000 \\
\hline
\end{tabular}

\section{Discussion of Findings}

The GARCH model, as an estimation technique for time variant conditional variance and nonlinearities in generating mechanism, provides good fit for stock returns volatility and hence the results obtained could be reliable. However, the observed volatility clustering and the presence of ARCH and GARCH in the automobile, banking and beverages sectors indicate interdependency of the series of returns. Because even where the variance equation of the GARCH indicate volatility clustering, the returns could be deterministic in nature, lending credence to possible linear dependency of previous returns and current returns. These situations may not have been peculiar to the Nigerian capital market, as an emerging market that is fraught with the challenges of effective information asymmetry and ethical practices 
until recently.

The study notes that outside the agricultural sector there is positive and significant relationship between risk and return which is in sync with theoretical construct. The off-curve finding in the agricultural sector, as noted previously can be explained from the perspective of its high-risk nature that usually repels investors in the normal course of business. In other words, what attracts investors to the agricultural sector is the promise of high returns characterized by direct government intervention in most cases. For instance since the inception of the present administration in 2010, so much attention has been given to the agricultural sector because of government's determination to make the agricultural sector the hub of the economy as part of the diversification strategy because of the vagaries associated with crude oil exports that have remained the main source of economic sustenance over the years.

Nonetheless, the results of the other sectors show a unidirectional relationship between volatility and returns, other than being in sync with theory, has remained the fulcrum of finance theory. This is more so that the reward to risk is the expected returns, which either offers commensurate benefits or earns a premium. It would serve as a disincentive if investors are not promised higher returns for investing in assets with risky characteristics. It thus infers that when investors invest on assets that are risky they are assured of higher returns since risk (volatility) move in the same direction.

\section{Conclusion and Recommendations}

The pattern of stock price movements in the four sub-sectors of the Nigerian capital market namely, agricultural, automobile, banking and beverages sectors, were investigated using the Runs and GARCH techniques for the period January 2006 to December 2011. The Runs test results reveal that stocks of the selected sectors do not move at random, indicating lack of stochastic behavior. In other words, these sectors in the Nigerian capital market demonstrate weak form inefficiency. Looking at the results of the GARCH mean model at lag one so as to further amplify our finding, we discovered that with the exception of the Agricultural Sector, stock returns demonstrate volatility clustering, and this indicates autocorrelation and weak-form inefficiency (Emenike, 2008). Thus, the results of the Runs test and GARCH technique seemingly suggest that stock prices in these sectors of the market do not show stochastic behavior and hence cannot be said to be efficient in the weak form.

The findings portend a situation where investors, with clear analytical capacity can predict future returns from previous returns and can make substantial gains by investing in those sectors of the Nigerian capital market. A critical study of the risk profile of the sectors, particularly the sectors with positive and unidirectional risk-return relationship presents opportunities for investors to leverage since there is the likelihood of earning higher returns in these sectors. But this would require regular monitoring as the dynamics of the economy and the market could change a given asset characteristics overtime.

We therefore recommend that there should be proper strengthening of policy framework as well as improved communication infrastructure to facilitate information dissemination. This 
will contribute to repositioning the entire operational framework of the market in pursuit of its fundamental mandate of deepening the economic growth of the country.

\section{References}

Adams, A., Bloomfield, D., Booth, P., \& England, P. (1993). Investment mathematics and statistics. Massachusetts: Kluwer Academic publishers Group, Norwell.

Adelegan, O. J. (2009). Price reactions to dividend announcements on the Nigerian capital market. AERC Research Paper 188. Retrieved from price reactions to Dividend Announcement NCM. Pdf.

Ajao, M. G., \& Osayuwu, R. (2012). Testing the weak form of efficient market hypothesis in Nigerian capital market. Accounting and Finance Research, 1(1), 169-179. http://dx.doi.org/10.5430/afr.v1n1p169

Ayadi, O. (1984). The random walk hypothesis and behavior of share prices in Nigeria. The Nigerian journal of Economics and social Studies, 26(1), 57-71.

Beyond Capital Market Downturn. Online [Available]: http://www.thisdaylive.com/.../beyond-capital-market-downturn/

Brooks, C. (2008). Introductory Econometrics for finance (2nd ed.). Cambridge: Cambridge University Press. http://dx.doi.org/10.1017/CBO9780511841644

Dogu, M., Karacaer, S., \& Karan, M. B (2010). Empirical testing of insider trading in the lstanbul stock exchange. International Research Journal of Finance and Economics, 15, 97-107. Online [Available]: http://www.eurojournals.com/finance.htm

Echekoba, F. N., \& Ezu, G. K. (2012). Effective Market Hypothesis: A historical perspective (A study of Nigerian capital market). Kuwait Chapter of Arabian Journal of Business and Management Review, 1(8), 76-86.

Emenike, K. O. (2008). Efficiency across time: Evidence from the Nigerian Stock exchange. Online [Available]: http://mpra.ub.muenchen.de/22901/MPRA Paper No. 22901

Fama, E. F. (1965). Random walks in stock market prices. Journal of Business. http://dx.doi.org/10.1086/294743

Grossman, S. J., \& Stiglitz, J. E. (1980). On the impossibility of informational efficient markets. The American Economic Review, 70(3), 393-408.

Gujarati, D. N. S. (2007). Basic Econometrics (4th ed.). New Delhi: Tata Mcgraw-Hill Publishing Company Ltd.

Jennings, R., \& Starks, L. (1985). Information content and the speed of stock price adjustment. Journal of Accounting Research, 23(1), 336-350. 10.2307/2490922

Jensen, M. C. (1978). Some anomalous evidence regarding market efficiency. Journal of finance Economics, 6(2/3), 95-101. http://dx.doi.org/10.1016/0304-405X(78)90025-9 
Khan, A. Q., \& Ikram, S. (2010). Testing semi-strong form of efficient market hypothesis in relation to the impart of foreign institutional investors (FII) investments on Indian capital market. International Journal of Trade, Economics and Finance, 1(4), 373-379. http://dx.doi.org/10.7763/IJTEF.2010.V1.66

Maheu, J. M., \& McCurdy, T. H. (2007). Components of market risk and return. Journal of Financial Econometrics, 5(4), 560-590. http://dx.doi.org/10.1093/jjfinec/nbm012:

Mobarek, A., \& Keasykeavin (2000). Weak form efficiency of an emerging market: evidence from Dhaka stock market of Bangladesh. Online [Available]: E-m-h.org/Moke00.pdf

Nwezeaku, N. C., \& Okpara, G. C. (2010). The effects of financial deepening on stock market returns and volatility: evidence from Nigeria. Internal Research Journal of Finance and Economics, 40. Online [Available]: http:www:eurojournals.com/finance.htm

Nwosa, P. I., \& Oseni, I. O. (2011). Efficient market hypothesis and Nigerian stock market. Research Journal of Finance and Accounting, 2(12), 38-46.

Ogege, S., \& Ezike, J. E. (2012). The Nigerian capital market and economic development: A critical appraisal. International Business Research, 5(8), 228-236. http://dx.doi.org/10.5539/ibr.v5n8p228

Oke, M. O., \& Azeez B. A. (2012). A test of strong-form efficiency of the Nigerian Capital Market. Business System Review, 1(1), 10-26. Online [Available]: http://www.business-systems-review.Org

Okpara, G. C. (2010). Stock market prices and the random walk hypothesis: Further evidence from Garch model. The International Journal of Applied Economic and Finance, 4(2), 62-66. http://dx.doi.org/10.3923/ijaef.2010.62.66

Olowe, R. A. (1998). Stock splits and efficiency of the Nigerian stock market. African Review of Money, Finance and Banking. Online [Available]: www.jstor.org/stable/23026306

Pele, D. T., \& Voineagu V. (2008). Testing market efficiency via decomposition of stock return: Application to Romanian capital market. Romanian Journal of Economic Forecasting, 3, 63-79.

Seyhun H. N. (1986). Insiders' profit, cost of trading and market efficiency. Journal of Financial Economics, 16, 189-212. http://dx.doi.org/10.1016/0304-405X(86)90060-7

Wang, Y. (2003). Nonparametric tests for randomness. ECE 461 Project Report. Online [Available]: WWW.ifp.illinois.edu/-ywang11/paper/ECE461Proj.pdf-United states

Ziobrowski, A. J., W., Cheng, P., \& Ziobrowski B. J. (2011). Abnormal returns from the common stock investment of members of the U. S. House of Representatives. Business and Politics, 13(1). Online [Available]: http://www.bepress.com/bap/vol13/iss1/art4 


\section{Copyright Disclaimer}

Copyright for this article is retained by the author(s), with first publication rights granted to the journal.

This is an open-access article distributed under the terms and conditions of the Creative Commons Attribution license (http://creativecommons.org/licenses/by/3.0/). 